\title{
PARTIAL DEAFNESS TREATMENT IN CHILDREN: A PRELIMINARY REPORT OF THE PARENTS' PERSPECTIVE
}

\author{
Anita Obrycka ${ }^{1,2}$, Jose-Luis Padilla ${ }^{3}$, Joanna Putkiewicz-Aleksandrowicz ${ }^{1,2}$, Artur Lorens ${ }^{1,2}$, \\ Henryk Skarzynski, ${ }^{1,2}$
}

${ }^{1}$ Institute of Physiology and Pathology of Hearing, ul. Zgrupowania AK "Kampinos" 1, 01-943 Warszawa, Poland

${ }^{2}$ World Hearing Center, ul. Mokra 17, Kajetany 05-830 Nadarzyn, Poland

${ }^{3}$ Dept. Social Psychology and Methodology of the Behavioural Sciences, University of Granada, Spain

Corresponding author: Anita Obrycka, e-mail: a.obrycka@ifps.org.pl

\begin{abstract}
Background: Cochlear implant (CI) eligibility criteria have broadened recently to include individuals with partial deafness (PD). In 2002, the Institute of Physiology and Pathology of Hearing, Poland, pioneered a particular technique of cochlear implantation termed partial deafness treatment (PDT) and achieved unrivalled rates of functional hearing preservation. Encouraged by the results in adults, a pediatric PDT program was initiated in 2004. The outcome of PDT for both adults and children has been well documented and assessed with objective measures of sound detection and speech discrimination. The current study explores outcomes in real life rather than in a clinical setting. We hypothesized that if PDT provides children with renewed listening ability it is likely to have a major impact on family life and that this impact should be able to be documented by parental reports.
\end{abstract}

Material and method: Seven parents of PDT cochlear-implanted children were surveyed using 20 open-ended prompts. The questionnaires were sent to patients' homes. The parents were asked to answer the prompts in their own words.

Results: All parents reported that after their child received cochlear implant there was a significant improvement in speech understanding and better perception of high pitched sounds. More than half the parents also noticed positive changes in speech production. The changes in communication abilities after CI positively influenced the child's relationships with family members and school mates.

Conclusions: The results of this study support expanding the criteria for receiving a cochlear implant to include children with partial deafness.

Key words: partial deafness treatment $\bullet$ cochlear implant $\bullet$ children $\bullet$ pediatric outcomes $\bullet$ qualitative methods

\section{TRATAMIENTO DE LA SORDERA PARCIAL EN LOS NIÑOS: UN INFORME PRELIMINAR DE LA PERSPECTIVA DE LOS PADRES}

\section{Resumen}

Antecedentes: Los criterios de elegibilidad de implantes cocleares (IC) se han ampliado recientemente para incluir a las personas con sordera parcial (PD). En 2002, el Instituto de Fisiología y Patología de la Audición en Polonia, pionero en una técnica concreta de la implantación coclear llamada tratamiento de la sordera parcial (PDT), alcanzó tasas sin par en la preservación de la audición funcional. Alentados por los resultados en adultos, se inició un programa de pediatría PDT en el año 2004. El resultado de la terapia PDT para adultos y niños ha sido bien documentado y evaluado con medidas objetivas de la detección de sonido y la discriminación del habla. El presente estudio analiza los resultados en la vida real en lugar de hacerlo en un entorno clínico. Nuestra hipótesis es que, si PDT proporciona a los niños la capacidad de escucha renovada, es probable que tenga un impacto importante en la vida familiar y por lo tanto este impacto debe ser documentado por informes parentales.

Materiales y método: Siete padres de niños con implantes cocleares en el tratamiento PDT fueron encuestados con 20 preguntas abiertas. Los cuestionarios fueron enviados a casa de los pacientes. Se pidió a los padres que respondieran a las preguntas con sus propias palabras.

Resultados: Todos los padres informaron que después de que su hijo recibiera un implante coclear hubo una mejora significativa en la comprensión del habla y una mejor percepción de los sonidos agudos. Más de la mitad de los padres también notaron cambios positivos en la producción del habla. Los cambios en las habilidades de comunicación después del IC influyeron positivamente en las relaciones del niño con sus familiares y compañeros de clase. 
Conclusión: Los resultados de este estudio apoyan la ampliación de los criterios de recepción de implantes cocleares para incluir en ellos a niños con sordera parcial.

Palabras clave: tratamiento de sordera parcial • implante coclear • niños • resultados pediátricos • método cualitativo

\section{TRAITEMENT DE LA SURDITÉ PARTIELLE CHEZ LES ENFANTS: RAPPORT PRÉLIMINAIRE SUR L'ÉVALUATION DES RÉSULTATS PAR LES PARENTS}

\section{Résumé}

Contexte: Les critères d’éligibilité aux implants cochléaires se sont élargis pour inclure les personnes atteintes de surdité partielle. En 2002, l'Institut de physiologie et de pathologie de l'audition Polonais a mis au point une technique particulière de l'implantation cochléaire appelé «traitement de la surdité partielle» et atteint des taux inégalés de préservation fonctionnelle de l’audition. Encouragé par les résultats chez les adultes, un programme pédiatrique de traitement de surdité partielle a été lancé en 2004. Le résultat du traitement de surdité partielle pour les adultes et les enfants a été documenté et évalué par des mesures objectives de détection sonore et de capacité de perception du discours. Cette étude montre les résultats obtenus dans la vie quotidienne plutôt que dans un contexte clinique.

Nous émettons l'hypothèse que si le traitement de surdité partielle offre aux enfants une capacité d'écoute accru, il est susceptible d’avoir un impact majeur sur la vie familiale et que cet impact devrait pouvoir être documenté par le biais des parents.

Matériel et méthode: Sept parents d’enfants avec implant cochléaire ont été interrogés grâce à un questionnaire de 20 questions ouvertes. Les questionnaires ont été envoyés au domicile des patients. Les parents ont été priés de répondre aux questions en utilisant leurs propres mots.

Résultats: Tous les parents ont déclaré une amélioration significative de la compréhension de la parole et une meilleure perception de sons aigus après l'implantation cochléaire chez leur enfant. Plus de la moitié des parents ont également remarqué une amélioration de la parole. Les changements des capacités de communication après implants cochléaires ont positivement influencés les relations de l'enfant avec les membres de la famille et les camarades de classe.

Conclusion: Les résultats de cette étude confirme lélargissement des critères déligibilité aux implants cochléaires aux enfants atteintes de surdité partielle.

Mots clés: traitement de surdité partielle • implant cochléaire • enfants • résultats pédiatriques • méthode qualitative

\section{ЛЕЧЕНИЕ ЧАСТИЧНОЙ ГЛУХОТЫ У ДЕТЕЙ: ПРЕДВАРИТЕЛЬНЫЙ ОТЧЕТ ПО ВОПРОСАМ ТОЧКИ ЗРЕНИЯ РОДИТЕЛЕЙ}

\section{Краткое изложение}

История вопроса: Критерии отбора пациентов для кохлеарной имплантации (CI) в недавнее время были расширены с включением пациентов с частичной глухотой (PD). В 2002 г. Институт физиологии и патологии слуха, Польша, впервые предложил особую методику кохлеарной имплантации, названную «лечение частичной глухоты» (PDT) и достиг непревзойденных результатов в сохранении функционального слуха. Основываясь на положительных результатах у взрослых пациентов, в 2004 г. была открыта программа лечения частичной глухоты в педиатрии. Результаты лечения частичной глухоты у взрослых и детей были детально документированы и оценены с привлечением объективных критериев выделения звука из окружающего шума и разборчивости речи. В настоящем исследовании приведены результаты, полученные не в лечебных учреждениях, а в естественном окружении. Мы сделали предположение, что лечение частичной глухоты, позволяющее восстановить остроту слуха у детей, будет оказывать значительное воздействие на семейную жизнь, и такое воздействие можно документировать в отчетах родителей.

Материалы и методы: Проведены опросы семерых родителей детей с показаниями к лечению частичной глухоты путем кохлеарной имплантации с применением 20 запросов без ограничений времени. Опросники были высланы на домашние адреса родителей. Родителям было предложено ответить на запросы, применяя собственную формулировку.

Результаты: Все родители сообщили, что их дети после установки кохлеарного имплантата продемонстрировали значительные улучшения в распознавании речи и лучшее восприятие высокочастотных звуков. Более половины 
родителей также отметили положительные изменения в речи. Изменения коммуникативных возможностей после CI положительным образом влияли на отношения ребенка с членами семьи и одноклассниками.

Заключение: Результаты настоящего исследования подтверждают целесообразность расширения критериев для установки кохлеарного имплантата с включением детей, страдающих частичной глухотой.

Ключевые слова: лечение частичной глухоты • кохлеарный имплантат • дети • достижения педиатрии • качественный метод

\section{Background}

Cochlear implant (CI) eligibility criteria have broadened recently to include new groups of patient. One distinct group of CI candidates consists of individuals with partial deafness (PD) who have usable acoustic hearing prior to implantation (mild to moderate hearing loss at low frequencies and profound hearing loss at high frequencies). In 2002, the Institute of Physiology and Pathology of Hearing, Poland, pioneered a particular technique of partial deafness cochlear implantation termed partial deafness treatment (PDT) and achieved unrivalled rates of functional hearing preservation $[1,2]$. Functional preservation implies that the individuals can be fitted both electrically and acoustically (through amplification) in the same ear, or can use nonamplified preserved natural lowfrequency hearing complemented by electric stimulation with a cochlear implant.

Encouraged by results in adults, a pediatric PDT program was initiated in 2004. The benefits of PDT for both adults and children have been well documented and have been mainly assessed using objective measures of sound perception and speech discrimination [1-9]. However, benefits from cochlear implantation are not limited to just better speech discrimination, but embrace various transformations in physical, psychological, and social functioning. To clearly understand the complex changes experienced by children and their families after cochlear implantation it is necessary to use subjective questionnaires tailored for the individual patient groups.

Subjective benefits after conventional cochlear implantation in profoundly deaf children have been assessed with a wide range of parental questionnaires, as parents are likely to be the primary source of information about children [10-12]. However, these techniques have not been used so far in children with PD who are a new and unique group of CI candidates for whom cochlear implantation can be considered a controversial intervention. PD children having 3-frequency $(500,1000,2000 \mathrm{~Hz})$ pure tone average (PTA) better than $75 \mathrm{~dB}$ in the ear to be implanted fall outside the recently broadened selection criteria for CI which includes children with residual hearing but with PTA in the implanted ear worse than $95 \mathrm{~dB}$ HL [13].

The reason that PD children are not commonly considered for cochlear implantation is twofold. Firstly, it is feared that this intervention might damage the functioning part of the cochlea and that the loss of acoustic hearing will have a detrimental effect on speech discrimination. Secondly, there is a concern that even if the postimplant speech discrimination scores exceed preimplant scores, this change might not be significant big enough to trigger the expected changes in the child's and family's functioning. Whereas in previous papers we have demonstrated a high rate of hearing preservation and improvement in speech discrimination in all children after PDT [1-9], the current study explores outcomes in real life rather than in the clinical situation. Our hypothesis was that if PDT provides children with renewed listening abilities then it is likely to have a major impact on the child and on family life and that these impacts should be apparent from parental reports.

There is another important practical reason to investigate parents' perception of the benefits from PDT intervention. One needs to remember that parents, when considering a cochlear implant for their child, are making a decision for the rest of their lives. Mixed and ambiguous information about PDT is likely to increase parental anxiety and hesitation when deciding whether to proceed with a cochlear implant. The experiences of parents probed by a questionnaire may help other parents make this pivotal decision.

Questionnaires can be designed for a wide range of purposes and for diverse populations in terms of magnitude, background, and specific demographic profiles [14]. The format of the questions depends on the purpose of the questionnaire. Aiken (1997) stated that open-ended questions are especially valuable in exploratory research and when a more detailed picture of the respondent's perceptions, opinions, thoughts, etc., is needed [14]. Schuman and Presser (1996) gave two major arguments in favor of open-ended questions: a) closed questions may fail to provide an appropriate set of alternatives meaningful to respondents; and b) respondents are apt to be influenced by the specific closed alternatives given, preventing the researcher from obtaining a wider picture of the respondent's experiences [15]. After recognizing that recommendations for one particular format are often grounded more firmly on "common sense" rather than on empirical findings, Foddy (1993) summarized the most important approaches to take when asking open questions: a) allow respondents to express themselves in their own words; b) do not suggest answers; c) avoid format effects; and d) allow complex motivational influences and frames of reference to be identified [16]. Taking these theoretical assumptions into consideration, we decided to use an open-ended questionnaire in order to explore parent's perspectives on outcomes after PDT in their children.

\section{Material and method}

A bibliographic review of the topic and insights provided by therapists who deal with partially deaf children contributed to determining the areas of interest for parental 
Table 1. Framework for reporting parental responses.

\begin{tabular}{lc}
\hline \multicolumn{1}{c}{ Areas of interest } & Prompt number \\
\hline $\begin{array}{l}\text { Child's functioning before } \\
\text { implantation }\end{array}$ & 1 \\
\hline Decision-making & 2 \\
\hline Difficult moments & 3 \\
\hline $\begin{array}{l}\text { Changes in communication } \\
\text { abilities after cochlear } \\
\text { implantation }\end{array}$ & $4,5,6$ \\
\hline $\begin{array}{l}\text { Effect of changes in } \\
\text { communication abilities on } \\
\text { patient's and family's life }\end{array}$ & $7,8,9,10,11,12,15,18,19$ \\
\hline $\begin{array}{l}\text { Appraisal of the decision } \\
\text { Future concerns }\end{array}$ & 16 \\
\hline $\begin{array}{l}\text { Advice for other parents in a } \\
\text { similar situation }\end{array}$ & 17 \\
\hline
\end{tabular}

survey, which are shown in Table 1 . To cover the areas some of the prompts proposed in a previous study by Archbold and colleagues were used [10]. As the aim of this study was to examine the impact of cochlear implantation on the life of the patient and the family, we focused directly on these areas. Specific questions were constructed to elicit more detailed information and explore changes. The areas covered and the number of prompts used for each are shown in Table 1. Another reason for selecting some prompts of Archbold and colleagues was to compare our results with those of the profoundly deaf children from that study [10]. The final open-format schedule consisted of 20 open-ended prompts listed in Appendix 1. Parents were asked to answer the prompts in their own words, without any specific suggestions.

From the group of 41 PDT children (PTA for 500, 1000, and $2000 \mathrm{~Hz}$ better than $75 \mathrm{~dB}$ ) implanted in the Institute of Physiology and Pathology of Hearing in Warsaw before June 2009, 21 parents of children with at least 2 years experience with CI were selected for the survey. The mean age at implantation in this group was 9.9 years, and the mean experience with a cochlear implant was 3.2 years.

Questionnaires were sent to patients' homes so they could choose the most suitable time for completing the task. Parents were asked to send the questionnaire back to the Institute within 1 month. In response, 12 questionnaires were sent back to the Institute, although 5 were not fully completed (more than $50 \%$ of the answers were missing). The analyzed sample therefore consisted of 7 fully completed questionnaires.

All children in this group of 7 had no additional disabilities, were in mainstream education, and lived in hearing families. Age at implantation ranged from 6-12.1 years (mean 9.0 years); age at testing ranged from 9.6-14.7 years (mean 12.5 years). Experience with CI ranged from 2.7 to 4.6 years, mean 3.5 years. Figure 1 shows the average preoperative and postoperative hearing thresholds of the implanted ears in the study group.

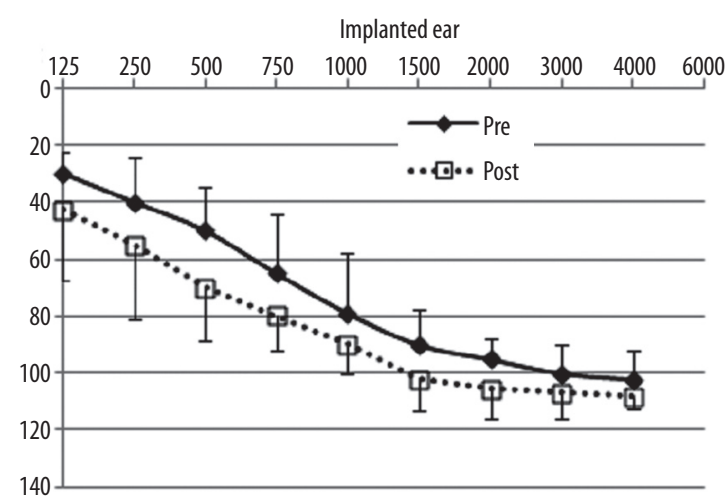

Figure 1. Average preoperative and postoperative hearing thresholds of the implanted ears in the study group.

Table 2. Child's functioning before implantation.

\begin{tabular}{lc}
\hline Child's functioning before implantation & $\begin{array}{c}\text { No. of } \\
\text { responses }\end{array}$ \\
\hline Communication problems & 7 \\
\hline Frustrated & 5 \\
\hline Low speech skills & 5 \\
\hline Withdrawn & 4 \\
\hline Shy & 3 \\
\hline Problems with high-pitched sounds & 3 \\
\hline
\end{tabular}

\section{Results}

This section presents the areas in the order asked, along with the list of themes most frequently raised by the parents and the number of respondents who raised each theme. Selected quotes are added to illustrate a patient's points of view and to emphasize the strength of their opinions.

\section{Child's functioning before implantation}

After analyzing the parents' responses about how their child functioned before implantation, we found that the most commonly raised themes were communication problems and some temperament and personality characteristics of the child (Table 2).

The following transcripts illustrate the sort of communication problems and specific situations in which problems occurred.

"Our child couldn't hear or understand high-pitch frequency sounds. Communication with the child was difficult." (12.5 years old at implantation; 2.8 years experience with CI; respondent, mother).

Parents spoke of difficulties in communication together with some social functioning problems.

"Often used to get angry when our communication wasn't good enough. Problems with communication would occur 
Table 3. Arguments for decision-making.

\begin{tabular}{lc}
\hline \multicolumn{1}{c}{ Decision-making } & $\begin{array}{c}\text { No. of } \\
\text { responses }\end{array}$ \\
\hline Speech understanding & 7 \\
\hline Communication improvement & 6 \\
\hline
\end{tabular}

Table 4. Difficult moments after cochlear implantation.

\begin{tabular}{lc}
\hline \multicolumn{1}{c}{ Difficult moments } & $\begin{array}{c}\text { No. of } \\
\text { responses }\end{array}$ \\
\hline No difficulties & 3 \\
\hline First months with $\mathrm{Cl}$ & 2 \\
\hline Operation and shortly after & 2 \\
\hline
\end{tabular}

throughout his daily life, starting from playing with his peers and ending on his behavior in the kindergarten and at home." (4.1 years old at implantation; 3.5 years experience with CI; respondent, mother).

"She was really shy and her speech very unintelligible and poor. She rather kept aloof from strangers and didn't speak in an unknown environment. She lip-read most of the time." (9 years old at implantation; 3.6 years experience with CI; respondent, mother).

\section{Decision-making}

The strongest argument for making the decision in favour of cochlear implantation was the perspective of better speech understanding and improvement in communication (Table 3).

Parents saw these aspects as the factor with most influence on the child's future functioning:

"It made us believe that after the operation our child would hear better and the communication with its environment and peers would be improved." (4.1 years old at implantation; 3.5 years experience with CI; respondent, mother).

"Make her life easier so she could hear well and develop her speech abilities and understanding." (9 years old at implantation; 3.6 years experience with CI; respondent, mother).

"Because it was impossible to communicate with our son and we couldn't help him in any way." (6.5 years old at implantation; 3.4 years experience with CI; respondent, mother).

\section{Difficult moments}

Some parents mentioned the postoperative period associated with the healing process and getting used to new sounds after the speech processor was switched on (Table 4).

Parents pointed out the bad mood of children shortly after the operation, fears connected with the functioning of the internal parts, and worries about the acceptability of the new sounds heard via the speech processor:
Table 5. Changes in communication abilities after cochlear implantation.

\begin{tabular}{lc}
\hline $\begin{array}{c}\text { Changes in communication abilities } \\
\text { after } \mathbf{C l}\end{array}$ & $\begin{array}{c}\text { No. of } \\
\text { responses }\end{array}$ \\
\hline Better speech understanding & 7 \\
\hline Hearing of new sounds & 7 \\
\hline Better communication & 6 \\
\hline Broader vocabulary & 5 \\
\hline Better pronunciation & 4 \\
\hline
\end{tabular}

"The first two months after the operation were the most difficult, as the speech processor wasn't turned on yet and our son didn't wear hearing aids. The beginning of rehabilitation with the processor was also hard." (6.5 years old at implantation; 3.4 years experience with $\mathrm{CI}$; respondent, mother).

"Postoperative period was the most difficult. The child was in a bad mood, it often felt dizzy and suffered from headaches." (10.8 years old at implantation; 2.5 years experience with $\mathrm{CI}$; respondent, mother).

"Whether the implant would be accepted and whether it would not be defective. We were also concerned if our child would accept the implant." (12.5 years old at implantation; 2.8 years experience with CI; respondent, mother).

Changes in communication abilities after cochlear implantation

After cochlear implantation parents noticed improvement in speech understanding and awareness of new sounds, especially high-pitched sounds. Respondents also pointed out improvement in pronunciation and broadening of their children's vocabulary (Table 5). These changes led to better communication:

"Her speech understanding has improved. She can now understand what other people say to her and what they say to each other. Her pronunciation and speaking skills during conversation with other people are also much better." (12.5 years old at implantation; 2.8 years experience with $\mathrm{CI}$; respondent, mother).

"We have noticed very significant changes in all these areas, communication skills are getting much better. He is more self-confident, his speech has become very fluent now. He also understands what we say to him very well." (4.1 years old at implantation; 3.5 years experience with CI; respondent, mother).

"Significant changes in the perception of sounds. She can hear almost every sound. She can also watch $T V$, listen to $m u$ sic and radio. What is more, she is now able to understand the meaning of more words." (12.1 years old at implantation; 2.7 years experience with CI; respondent, mother).

"Speech understanding has improved, her vocabulary is much broader, her syntax is better, but it hasn't reached the 
Table 6. Effect of changes in communication abilities on patient's and family's life.

\begin{tabular}{lc}
\hline $\begin{array}{c}\text { Effect of changes in communication } \\
\text { abilities on patient's and family life }\end{array}$ & $\begin{array}{c}\text { No. of } \\
\text { responses }\end{array}$ \\
\hline Better relationships & 7 \\
\hline More self-confident & 6 \\
\hline More independent & 6 \\
\hline More open & 5 \\
\hline Talkative & 5 \\
\hline Better understanding of TV programs & 5 \\
\hline Became cheerful & 4 \\
\hline Music appreciation & 4 \\
\hline Improvement in school & 4 \\
\hline Telephone use & 3 \\
\hline
\end{tabular}

highest level yet." (9 years old at implantation; 3.6 years experience with CI; respondent, mother).

"Hear high-pitch frequency sounds perfectly." (6.7 years old at implantation; 2.8 years experience with $\mathrm{CI}$; respondent, mother).

Effect of changes in communication abilities on patient's and family's life

Cochlear implant has also had a great impact on the patient's life in many domains. Relationships with peers and family have improved. Children became more independent and self-confident. They started to use the telephone or Skype. They started to listen to music and watched television more willingly (Table 6).

Subsequent transcripts show the domains in the child's life which were influenced by a change in hearing abilities:

"Our son enjoys taking part in the kindergarten activities and makes significant progress." (4.1 years old at implantation; 3.5 years experience with CI; respondent, mother).

"She can hear well when watching television and listening to music and radio on her computer. She understands the plot in movies with voice-over narration. She does not rely on lip-reading when watching Polish films and programs." (12.5 years old at implantation; 2.8 years experience with CI; respondent, mother).

"Enjoys listening to music and watching cartoons. When playing computer games, he uses hints pronounced by a reader. He knows and sings many songs from cartoons." (6.7 years old at implantation; 2.8 years experience with CI; respondent, mother).

"The change is significant. She can understand speech both on the television and computer, which used to be a problem. Before the implantation she couldn't even hear the intercom sound." (9 years old at implantation; 3.6 years experience with CI; respondent, mother).
Table 7. Appraisal of the decision.

\begin{tabular}{cc}
\hline Appraisal of the decision & $\begin{array}{c}\text { No. of } \\
\text { responses }\end{array}$ \\
\hline Glad about the decision & 7 \\
\hline Significant change & 6 \\
\hline Not much has changed & 1 \\
\hline
\end{tabular}

Table 8. Future concerns.

\begin{tabular}{lc}
\hline Future concerns & $\begin{array}{c}\text { No. of } \\
\text { responses }\end{array}$ \\
\hline Education & 7 \\
\hline Future job & 6 \\
\hline Device failure & 4 \\
\hline
\end{tabular}

"She understands her teacher better and her learning skills at school have improved. It is also easier for her to communicate with her classmates." (12.1 years old at implantation; 2.7 years experience with CI; respondent, mother).

"He has become very cheerful, more independent and selfreliant. He asks a lot questions and can understand sometimes really complicated answers." (4.1 years old at implantation; 3.5 years experience with CI; respondent, mother).

Appraisal of the decision

Overall, parents do not regret their decision, and most of them described the change after cochlear implantation as significant (Table 7).

Parents are confident they made a decision that helped their children, and they are glad they were able to find a way to improve the quality of life of their child and the whole family:

"She started to hear all that she couldn't hear before and when she started to speak more fluently we knew that we did all that was possible to do in order to help our child live a normal life. I believe that the decision on implantation was the right one." (12.5 years old at implantation; 2.8 years experience with CI; respondent, mother).

"He wasn't watching, he was listening and it was a wonderful image." (4.1 years old at implantation; 3.5 years experience with CI; respondent, mother).

"To be honest, not many changes took place in our son's life. I think that brain maturity is also a determining factor in this case." (10.8 years old at implantation; 2.5 years experience with CI; respondent, mother).

\section{Future concerns}

The greatest concern of parents with regard to their child's future related to their education and potential job (Table 8). 
Table 9. Advice for other parents in a similar situation.

\begin{tabular}{lc}
\hline \multicolumn{1}{c}{$\begin{array}{c}\text { Advice for other parents in a similar } \\
\text { situation }\end{array}$} & $\begin{array}{c}\text { No. of } \\
\text { responses }\end{array}$ \\
\hline Encourage other parents & 7 \\
\hline Don't postpone the decision & 5 \\
\hline Take advantage of others experience & 3 \\
\hline
\end{tabular}

They also worried about failure of the cochlear implant or speech processor:

"Probably our biggest worries are connected with her education, finishing all the schools, and later with finding a job." (9 years old at implantation; 3.6 years experience with CI; respondent, mother).

"We worry about his education, what profession he will choose and will he be able to afford a new speech processor?" (6.5 years old at implantation; 3.4 years experience with CI; respondent, mother).

"Implant damage and its replacement." (4.1 years old at implantation; 3.5 years experience with CI; respondent, mother).

\section{Advice for other parents in a similar situation}

Because parents don't regret the decision about cochlear implantation, they would encourage other parents in a similar situation to do the same. Contact with parents in a similar situation after the treatment was seen as helpful (Table 9).

The following transcripts illustrate the parents' point of view:

"It is really worthwhile to do it. All those around us have noticed significant progress in our daughter's development." (9 years old at implantation; 3.6 years experience with CI; respondent, mother).

"Wouldn't hesitate. In my opinion, cochlear implantation improves the quality of social life of people with partial deafness." (12.1 years old at implantation; 2.7 years experience with $\mathrm{CI}$; respondent, mother).

"Individual decision. I believe that a child should be given an opportunity to develop better, develop speaking skills, and above all, speech understanding abilities. It has great influence not only on intellectual development, but also psychological and physical progress of a child. Parents should not listen to people who are incompetent, as they are bad advisors. It is sensible to talk to people who have already made their decisions and who are surely willing to share their experience, advice and doubts..." (6.7 years old at implantation; 2.8 years experience with CI; respondent, mother).

"to implant their children as early as possible and of course, not to forget about rehabilitation, rehabilitation and rehabilitation once more." (10.8 years old at implantation; 2.5 years experience with CI; respondent, mother).

\section{Discussion}

The present study is the first (to our knowledge) to document the real-life benefit of PDT in children with functional hearing preservation after cochlear implantation. In contrast to our two previous reports on pediatric PDT, which relied on hearing preservation and speech discrimination results [4-7], the current work is based on parental experiences.

Speaking of the benefits after a cochlear implant, one has to define the child's functioning before implantation. The results show that the PD child's low-frequency hearing was grossly insufficient for communication in everyday life, as all parents pointed to communication problems as the main characteristic of their child's functioning prior to implantation. This finding is not surprising, as children considered for PDT remain beyond the scope of effective treatment using hearing aids, considering that the benefits of conventional amplification depend not only on the degree of the hearing loss but vary considerably with the configuration.

The hearing loss of PD children from our study group was characterized by PTA for 3 frequencies $(500,1000$, and $2000 \mathrm{~Hz}$ ) better than $75 \mathrm{~dB}$ but at the same time, by profound deafness at high frequencies, with $2000 \mathrm{~Hz}$ thresholds worse than $90 \mathrm{~dB}$. Several studies report little or no benefit of high-frequency amplification when auditory thresholds exceed 55-60 dB HL at or above $2000 \mathrm{~Hz}$, and conclude that listeners with severe high-frequency losses remain at a significant disadvantage in all listening environments, presumably due to nonfunctional or dead regions in the cochlea [17-19]. Recently Stelmachowicz and colleagues [20] investigated the contribution of high-frequency audibility to speech perception in children with hearing loss, and found that mid-frequency audibility (2-4 $\mathrm{kHz}$ ) appeared to be the most important for perception of fricatives for male speakers and a wider frequency range (2-8 kHz) was important for female speakers.

For PD children, audibility over both ranges is inadequate due to the profound high-frequency loss. Unfortunately, the limited bandwidth of current hearing aids would reduce high-frequency audibility even further. The highfrequency gain of behind-the-ear hearing aids, which are most appropriate for young children, drops off abruptly above $5 \mathrm{kHz}$, well below the peak frequencies of consonant $/ s$ / spoken by children and women. In addition, providing adequate gain in the $6-8 \mathrm{kHz}$ range is difficult in young children because acoustic feedback is common [20].

Lack of proper audibility of high-frequency speech cues also adversely affects the child's ability to adequately monitor their own speech. From the outcomes quoted above it is clear that PD, being a profound high-frequency hearing loss, significantly impairs speech and language development in children. This is reflected in the first and the second themes most frequently cited by parents: that is, communication problems and low speech skills. Interestingly, problems with communication in children considered for partial deafness treatment seem to have the same consequences as lack of communication found by Archbold and colleagues in profoundly deaf children who were 
standard CI candidates [10]. In both groups one of the most common terms used by parents to describe children before implantation was "frustrated, quiet and shy". In our study almost half the parents mentioned problems with perception of high-pitch sounds which indicates a "partial" type of deafness. In the group of standard CI candidates, parents tended to describe their children as "deaf".

The key finding of this study was that all parents reported significant improvement in speech understanding and better perception of high-pitched sounds in their child after cochlear implantation. Parents attributed the improvement in communication abilities not to developing maturity, but to increased ability to hear high-frequency sounds. The dominant role of CI in changes of communication ability was highlighted by Skarzynski \& Lorens (2010) who investigated the rapid improvement in auditory capacity after PDT and suggested that the gains in performance were due to $\mathrm{CI}$ intervention rather then to any progress that might have occurred in the course of rehabilitation with conventional HAs [7]. These results support the belief that in cases of profound high frequency hearing loss, cochlear implants provide a better representation of high-frequency sounds than current hearing aids. For cochlear implants, frequencies as high as $8 \mathrm{kHz}$ are generally well represented.

More than half of the parents also noticed positive changes in speech production. This result is consistent with the outcomes of a study by Grant et al. [21]. The authors found that production accuracy of high-frequency fricatives was higher for the cochlear implant group compared to children using hearing aids.

The spectacular benefit reported by parents of PDT children is in line with the speech discrimination improvement demonstrated in children after PDT by Skarzynski et al. $[4,7]$. The benefit after cochlear implantation in individuals with $\mathrm{PD}$ is attributed not only to the improvement in high-frequency audibility but also to the sustained binaural acoustic hearing at low frequencies due to the successful hearing preservation in the implanted ear [6]. The combination of electric plus acoustic stimulation provides a more complete representation of speech frequencies than is possible with either modality alone [22].

The parents' perception of the magnitude of changes in their child's communication, and in family life generally, after the PDT are similar to those reported by Archbold and colleagues in a group of profoundly deaf children [10]. Communication skills improved in both groups and children became more self-confident. These changes positively affected their relationships with family members and school mates. The similarity of the results is surprising, as the groups differed tremendously in preoperative hearing abilities. Children with PD scored more than $30 \%$ in monosyllabic word tests in contrast to a complete lack of open speech discrimination in the group of traditional CI candidates. In spite of the fact that the children considered for partial deafness treatment were starting from a relatively high level, the results suggested that there was still room for improvement.

In our study there were some important factors, including comprehension of TV programs and music appreciation, which were not mentioned by parents in the Archbold et al. work [10]. On the other hand, some of the results found in the profoundly deaf CI group didn't appear in our material. Parents from the current study did not say that, as a factor in their decision making, they had nothing to lose, or that the cochlear implant was the chance for their children to hear. The reason for cochlear implantation for parents of PD children was an improvement in speech understanding and fluent communication rather than a chance for mainstream education and oral communication.

The last issue worth highlighting is that in the present study the parents' responses to the question concerning difficult moments after cochlear implantation revealed some worries connected to postsurgical condition of the child, functioning of the device, and reaction of the child to hearing "new" sounds. Parents should be counseled regarding the possible initial decline in speech perception performance due to the child's need to acclimatize to the high frequency sounds. An experienced team of specialist should assure parents that these initial problems may be overcome and help the family cope with solving them.

\section{Conclusion}

This study provides a detailed picture of parents' perceptions, opinions, and thoughts on PDT in a pediatric population as reflected in the outcomes of an open-ended questionnaire. The results demonstrate that PDT with cochlear implantation in children leads to an improvement in communication abilities which, as a consequence, influences the child's temperament and personality characteristics, and has an impact on the whole family's life and the child's school relationships. The results of this study support expanding the cochlear implant candidacy criteria to include children with PD.

\section{Appendix}

Appendix 1. List of the open-ended prompts sent to parents of children after PDT

1. How would you describe your child before cochlear implantation?*

2. Why did you decide to go ahead with the implant?*

3. What was the most difficult period after cochlear implantation and why?

4. What area of development has shown the most changes? e.g. communication, behavior, confidence, independence, language, speech?*

5. What change did you notice in your child's perception of environmental sounds?

6. What changes did you notice in your child's speech understanding ability?

7. To what extent did the new hearing skills influence your child's abilities of using media (radio, television, computer)?

8. What is the influence of new hearing skills on school performance?

9. What is the influence of new hearing skills on family life?

10. What is the influence of new hearing skills on child's interactions with peers?

11. What is the influence of new hearing skills on your child's hobbies and interests? 
12. To what extent did the new hearing skills influence your child's attitude towards itself (self-confidence, functioning in peer groups, handling difficult situations, etc.)?

13. In what way did the attitude of your environment change with respect to your child after cochlear implantation?

14. How would you describe your child now?*

15. What do you feel the implant has enabled your child to do what would have been impossible without it? (Thinking of schooling, independence, family relationships, friendship etc.)*
16. Which moment in your child's life convinced you that cochlear implantation was a good decision?

17. What areas of concern do you have now for the future? ${ }^{\star}$

18. To what extent has the scope of assistance provided to your child changed in comparison with the situation before the implantation? (Thinking of education, communication, independence, etc.)

19. Has there been any effect on other members of the family from the implantation? *

20. What advice would you give to other parents thinking about implantation? ${ }^{*}$

The prompts marked by an asterisk are selected from Archbold et al. 2002 [10].

\section{References:}

1. Skarzynski H, Lorens A, Piotrowska A: A new method of partial deafness treatment. Med Sci Monit, 2003; 9(4): CS20-24

2. Skarzynski H, Lorens A, Piotrowska A, Anderson I: Preservation of low frequency hearing in partial deafness cochlear implantation (PDCI) using the round window surgical approach. Acta Oto-laryngologica, 2007; 127(1): 41-48

3. Skarzynski H, Lorens A, Piotrowska A, Anderson I: Partial deafness cochlear implantation provides benefit to a new population of individuals with hearing loss. Acta Otolaryngol. 2006; 126(9): 934-40

4. Skarzynski H, Lorens A, Piotrowska A, Anderson I: Partial deafness cochlear implantation in children. Int J Pediatr Otorhinolaryngol, 2007; 71(9): 1407-13

5. Gifford RH, Dorman MF, Spahr AJ et al: Hearing preservation surgery: psychophysical estimates of cochlear damage in recipients of a short electrode array. J Acoust Soc Am, 2008; 124(4): 2164-73

6. Lorens A, Polak M, Piotrowska A, Skarzynski H: Outcomes of Treatment of Partial Deafness with Cochlear Implantation: A DUET Study. The Laryngoscope, 2008; 118(2): 288-94

7. Skarzynski H, Lorens A: Electric acoustic stimulation in children. Adv Otorhinolaryngol, 2010; 67: 135-43

8. Skarzynski H, Lorens A, Piotrowska A, Skarzynski PH: Hearing preservation in partial deafness treatment. Med Sci Monit, 2010; 16(11): CR555-62

9. Skarzynski H, Lorens A, Matusiak M et al: Partial deafness treatment with the nucleus straight research array cochlear implant. Audiol Neurotol, 2012; 17(2): 82-911

10. Archbold SM, Lutman ME, Gregory S et al: Parents and their deaf child: their perceptions three years after cochlear implantation. Deafness and Education International, 2002; 4(1): 12-40

11. Nikolopoulos TP, Lloyd H, Archbold S, O’Donoghue G: Pediatric Cochlear Implantation. The Parents' Perspective. Arch Otolaryngol Head Neck Surg, 2001; 127: 363-67
12. Huttunen $\mathrm{K}$, Rimmanen $\mathrm{S}$, Vikman $\mathrm{S}$ et al: Parents' views on the quality of life of their children 2-3 years after cochlear Implantation. Int J Pediatr Otorhinolaryngol, 2009; 73: 1786-94

13. Dettman SJ, D'Costa WA, Dowell RC et al: Cochlear implants for children with significant residual hearing. Arch Otolaryngol Head Neck Surg, 2004; 130(5): 612-18

14. Aiken LR: Questionnaires and inventories. New York: John Wiley \& Sons, Inc., 1997

15. Schuman H, Presser S: Questions \& answers in attitude surveys: Experiments on question form, wording and context. Thousand Oaks, CA: Sage Publications, 1996

16. Foddy W: Constructing questions for interviews and questionnaires. Theory and practice in social research. Cambridge: Cambridge University Press, 1993

17. Ching TY, Dillon H, Byrne D: Speech recognition of hearingimpaired listeners: predictions from audibility and the limited role of high-frequency amplification. J Acoust Soc Am, 1998; 103(2): 1128-40

18. Hogan CA, Turner CW: High-frequency audibility: benefits for hearing-impaired listeners. J Acoust Soc Am, 1998; 104(1): 432-41

19. Turner CW, Cummings KJ: Speech audibility for listeners with high-frequency hearing loss. Am J Audiol, 1999; 8(1): 47-56

20. Stelmachowicz PG, Pittman AL, Hoover BM et al: The Importance of High-Frequency Audibility in the Speech and Language Development of Children With Hearing Loss. Arch Otolaryngol Head Neck Surg, 2004; 130: 556-62

21. Grant L, Bow C, Paatsch L, Blamey P: Comparison of production of /s/ and /z/ between children using cochlear implants and children using hearing aids. Proceedings of the 9th Australian International Conference on Speech Science \& Technology; Australian Speech Science \& Technology Association Inc., Melbourne, 2002; 160-65

22. Wilson BS, Lawson DT, Muller JM et al: Cochlear implants: some likely next steps. Annu Rev Biomed Eng, 2003; 5: 207-49 